2ag. d. Pham. Sci., Vol. 1, No. (1-2), Nou. 1992

\title{
GC-MS ANALYSIS OF THE ESSENTIAL OIL OF COSMOS BIPINNATUS Cav. GROWING IN EGYPT
}

\author{
Moshera Mohamed El-Sherei \\ Department of Pharmacognosy, \\ Faculty of Pharmacy \\ Cairo University
}

\section{ABSTRACT}

The composition of hydrodistilled oils of the flower-heads and leaves of Cosmos bipinnatus was investigated by capillary gas chromatography coupled with mass spectrometry. Based on interpreling and comparing the resultant spectra with the available reported data, sixteen components were identified in the flower heads amounting to $91.58 \%$ and six in the leaves amounting to $98.28 \%$. Hydrocarbons were found predominent in both oils and alcohols are present in variable concentrations, but the oxides were found in the flower-heads oil only. Both oils showed pronounced antimicrobial activity against certain microorganisms.

\section{INTRODUCTION}

Genus Cosmos Cav. is a rather small genus ${ }^{(1)}$ of the tribe Helianthae (Astraceae), it comprises over 25 species distributed all over tropical America ${ }^{(2)}$. Plants belonging to this genus are characterized by their nicely coloured flowers ${ }^{(3)}$. Cosmos bipinnatus Cav. is an annual plant indigenous to Mexico ${ }^{(4)}$ and grows wild in Bolivia and Arizona ${ }^{(3)}$, now it is growing and flourishing in different localities in Egypt as an ornamental garden plant.

Cosmos species were previously reported ${ }^{(5)}$ to possess cytotoxic activity and proved to be effective against human epidemoid carcinoma of nasopharynx. 
Earlier examination of the essential oil ${ }^{(6)}$ of Cosmos bipinnatus among other nine plants belonging to family Astraceae cultivated in Norway ${ }^{(6)}$, reported the presence of a volatile hydrocarbon cosmene $\left(\mathrm{C}_{10} \mathrm{H}_{14}\right)$, identified as 2,6-dimethyl-octa-1,3,5,7-tetraene,which showed a four-bands UV absorption spectrum. this compound ( $\mathrm{mp}-2^{\circ} \mathrm{C}$ to $-1^{\circ} \mathrm{C}$, B.p $30^{\circ} \mathrm{C} / 33 \mathrm{~mm}$ ), was found to be utterly unstable in air and light, and rapidly polymerises to a white, insoluble solid material. Hence cosmene was obtained when steam distillation was carried out in a stream of nitrogen and the distillate stored under hydroquinone ${ }^{(6,7)}$. On the basis of the uv spectrum of cosmene and the biogenetic considerations, a synthetic route to this compound had been postulated ${ }^{(6,8)}$.

Concerning Cosmos bipinnatus Cav. growing in Egypt, a botanical study of its different organs, as well as, preliminary phytochemical and biological screenings were carried out ${ }^{(9)}$.

On accoumt of the study of the volatile oil of the plant, nothing was traced in the current literature except for the chemistry of cosmene. Thus, it was deemed of interest to analyze the essential oil of the flower heads and leaves of the plant and screen them for antimicrobial activity.

\section{MATERIALS AND METHODS}

\section{Plant Material:}

Fresh flower heads and leaves of Cosmos bipinnatus Cav. were collected from plants cultivated in the Experimental Station of Medicinal Plants of the Department of Pharmacognosy, Faculty of Pharmacy, Cairo University during July to October 1991. The plant was kindly identified by Dr. N. El- Hadidi, Professor of Plant Taxonomy, Faculty of Science, Cairo University, to whom the author is indebted.

\section{Preparation of the Oils:}

The oil from both fresh flower heads and leaves of $\underline{\mathrm{C}}$. bipinnatus Cav. was separately prepared by hydrodistillation [E.P. 1984] ${ }^{(10)}$. 
Zag. J. pharm. Sci., vol. 1, No. (1-2), Nov. 1992

\section{Gas (Jromalography- Mass Spectrometry (GO/MS):}

A Finnigan MA'T- 5100 series, GC/MS apparatus was used. The analyses of the oils were performed on capillary columns: $\left[\mathrm{BD}_{1}\right.$-methyl silicon, $30 \mathrm{~m} \times 0.22 \mathrm{~mm}$. (i.d.) for flower heads oil and $\mathrm{BD}_{5}-5 \%$ phenyl methyl silicon, $15 \mathrm{~m} \times 0.15 \mathrm{~mm}$ (i.d.) for leaves oil. Helium was the carrier gas at a rate of $40 \mathrm{ml} / \mathrm{min}$. The temperature programming range was 55 $300^{\circ} \mathrm{C}$ increased at the rate of $5^{\circ} \mathrm{C} / \mathrm{min}$, then isothermal for $3 \mathrm{~min}$. Temperatures of the injector and interface were $220^{\circ} \mathrm{C}$. The ion source was electron impact (E.I) at $70 \mathrm{e} \mathrm{v}$ and scan range 50-600.

Qualitative identification of the individual component was determined by interpreting their observed mass spectral data, as well as, comparing them with those reported in the literature (11-14). The peak area method was adopted for quantitative determination of different components, and the data obtained are listed in tables (1 \&2).

\section{Screening for Antimicrobial Activity:}

The prepared oil of the flower heads and leaves of C.bipinnatus Cav. at different concentrations; $100,200,300$ and $400 \mu \mathrm{g} / \mathrm{ml}$ were used for testing their antimicrobial activity against the selected microorganisms (Table 3); adopting the disc- agar diffusion method ${ }^{(15)}$. Ampicillin was used for comparison.

\section{RESULTS AND DISCUSSION}

The oil yield obtained by hydrodistillation of the flower heads and leaves of Cosmos bipinnatus Cav. was up to $0.1 \%$ and $0.05 \% \mathrm{v} / \mathrm{w}$ respectively. Both oils possessed characteristic persistant aroma and faint yellow colour with white deposits adhearing to the walls of the apparatus. The oils were freely soluble in ether, chloroform, absolute alcohol and $90 \%$ alcohol, while the white solids were insoluble in all organic solvents and water. 
(Table 2) : GC - MS analysis of the essential oil of the leaves of Cosmos bipinnatus (Cav.)

\begin{tabular}{|c|l|l|c|c|c|}
\hline $\begin{array}{c}\text { Peak } \\
\text { No }\end{array}$ & $\mathrm{R}_{\mathrm{t}}$ & \multicolumn{1}{|c|}{ Component } & $\mathrm{M}^{+}$ & B.P & Rel.\% \\
\hline 1 & $5: 26$ & $(-)-2$ Carene & 136 & 59 & 2.29 \\
2 & $6: 06$ & $(+)-4(10)$ Carene & 136 & 93 & 41.58 \\
3 & $6: 28$ & Unidentified * & -- & - & 0.44 \\
4 & $7: 09$ & Ocimene & 136 & 93 & 31.32 \\
5 & $7: 20$ & Unidentified * & -- & -- & 0.46 \\
6 & $8: 26$ & p-mentha-1,3,8- triene & 134 & 91 & 9.87 \\
7 & $9: 11$ & Terpinene - - - & 154 & 71 & 6.37 \\
8 & $12: 18$ & Unidentified * & - & - & 0.48 \\
9 & $13: 19$ & $\beta$-gurjunene & 204 & 161 & 6.85 \\
10 & $15: 40$ & Unidentified * & -- & -- & 0.30 \\
& & & & & \\
\hline
\end{tabular}

* Concentration in the oil is not sufficient to be analysed by the mass spectroneter, $R_{t}=$ retention time, $\mathrm{M}^{+}=$molecular ion, B.P. = Base peak, Rel. $\%=$
relative percentage.

(Table 3) : Results of antimicrobial screening of the flower heads and leaves of $\mathrm{C}$. bipinnatus (Cav.)

\begin{tabular}{|c|c|c|c|c|c|}
\hline \multirow{2}{*}{ Tested microorganism } & \multicolumn{4}{|c|}{ Conc. in ug/ml } & \multirow[b]{2}{*}{ Amp. } \\
\hline & $\begin{array}{l}100 \\
\text { F. H. L. }\end{array}$ & $\begin{array}{l}200 \\
\text { F. H. L. }\end{array}$ & $\begin{array}{l}300 \\
\text { F. H. L. }\end{array}$ & \begin{tabular}{l}
\multicolumn{2}{|c|}{400} \\
F. H. L.
\end{tabular} & \\
\hline$\underline{\text { Staphylococcus aureus }}$ & & & & + & + \\
\hline$\underline{\text { Bacillus subtilis }}$ & - - & & & & \\
\hline Streptococcus epidermides & & & & ++ & + \\
\hline Proterse vilarais & $-\cdot$ & $-\quad-$ & $-\cdot$ & $+\quad+$ & + \\
\hline Proteus vulgaris & $\cdot$ & $-\quad-$ & & $+\quad+$ & + \\
\hline Pseudomonas aerogenosa & & & & & + \\
\hline Escherichia coli & - . & & & & + \\
\hline Candida albicans & & & & & .- \\
\hline
\end{tabular}

+ means zone of inhibition $>10 \mathrm{~mm}$.

conc $=$ concentration $; \mathrm{F} . \mathrm{H} .=$ flower heads $; \mathrm{L} .=$ leaves $;$ Amp. $=$ ampicillin. 
zag. J. Pharm. Sci., Vol. 1, No. (1-2), Nov. 1992

Results of GC/MS analyses of the oils (Table 1 \&2) demonstrated the occurrence of at least 25 and 10 components in each of the flower heads oil and leaves oil, respectively. Only 19 components from the flower heads oil and 6 from the leaves oil were present in sufficient concentrations to be analysed by the mass spectrometer.

The rest of components failed to be analyzed and identified because they were present in trace amounts.

The analysis of the flower heads oil (Table 1) allowed the identification of 16 components (accounting to $91.58 \%$ ) of those analyzed by GC/MS (19 components). Hydrocarbons represented the most abundant group of the oil $(52.13 \%)$ followed by the alcohols ( $34.23 \%$ ) and lastly the oxides $(5.22 \%)$. Among the identified hydrocarbons, methyl bornene was the major (24.95\%), followed by $\beta$-elemene (4.86\%), (+)-4(10) carene $(4.6 \%), \gamma$ gurjunene (3.82\%), 2,8-dimethyl-3-isobutenyl-5-isopropyl dihydronaphthalene $(3.14 \%)$, dekalin (3.13\%), caryophyllene $(2.90 \%)$, longifolene $(2.57 \%)$ and bulnesene $(2.16 \%)$. Sabinol alcohol was found to be the second major component of the oil (20.07\%), followed by trans- nuciferol (6.44\%), pinocarveol (3.55\%), Cis-nuciferol (2.36\%) and $\alpha$-terpineol (1.81\%). Linalool oxide $(3.06 \%)$ and caryophellene oxide $(2.16 \%)$ could also be identified.

On the other hand, six components from the oil of the leaves were identified (Table 2), represented $98.28 \%$ of the oil. Hydrocarbons which constituted the bulk of the oil, being $91.91 \%$, the most prominent compound was $(+)-4(10)$ carene (41.58\%), followed by ocimene $(31.32 \%)$, pmentha $1,3,8$ triene $(9.87 \%), \beta$ - gurjunene $(6.85 \%)$ and (-)2-carene $(2.29 \%)$. Terpinene $-4-0 \mathrm{ol}(6.37 \%)$ could also be identified.

Comparing the composition of the two oils as represented by GC/MS: hydrocarbons were found in a prominent concentration in both oils (52.13\% and $91.91 \%$ in the flower heads and leaves respectively). The oil of the flower heads was characterized by the presence of high percentage of alcohols (34.23\%) while that of the leaves was relatively low (6.37\%). Oxides were detected only in the oil of the flower heads. The only common 
(Table 1) : GC - MS analysis of the essential oil of the flower heads of Cosmos bipinnatus (Cav.)

\begin{tabular}{|c|c|c|c|c|c|}
\hline $\begin{array}{l}\text { Peak } \\
\text { No }\end{array}$ & $\mathrm{R}_{\mathrm{t}}$ & Component & $\mathrm{M}^{+}$ & B.P & Rel.\% \\
\hline 1 & $3: 25$ & $(+)-4(10)$ Carene & 136 & 93 & 4.6 \\
\hline 2 & $4: 01$ & Unidentified * & -- & -- & 0.55 \\
\hline 3 & $4: 12$ & Methyl bornene & 136 & 80 & 24.95 \\
\hline 4 & $5: 00$ & Sabinol & 152 & 92 & 20.07 \\
\hline 5 & $5: 23$ & Linalool Oxide & 170 & 59 & 3.06 \\
\hline 6 & $5: 41$ & Pinocarveol & 152 & 91 & 3.55 \\
\hline 7 & $5: 50$ & $\alpha$-Terpineol & 154 & 59 & 1.81 \\
\hline 8 & $6: 06$ & Dekalin & 138 & 67 & 3.13 \\
\hline 9 & $6: 28$ & Unidentified * & -- & -- & 0.56 \\
\hline 10 & $7: 10$ & B-Elemene & 204 & 81 & 4.86 \\
\hline 11 & $7: 25$ & Caryophellene & 204 & 69 & 2.90 \\
\hline 12 & $7: 34$ & $\beta$ - Bulnesene & 204 & 108 & 2.16 \\
\hline 13 & $7: 55$ & $\gamma$-Gurjunene & 204 & 105 & 3.82 \\
\hline 14 & $8: 01$ & Longifolene & 204 & 91 & 2.57 \\
\hline 15 & $8: 12$ & Unidentified * & -- & -- & 0.34 \\
\hline 16 & $8: 44$ & Caryophellene Oxide & 220 & 79 & 2.16 \\
\hline 17 & $9: 11$ & Unidentified * & -- & -- & 0.06 \\
\hline 18 & $9: 39$ & $\begin{array}{l}\text { 2,8- dimethyl, } 3 \text { - isobutenyl, 5- } \\
\text { isopropyl dihydronaphthalene }\end{array}$ & 268 & 253 & 3.14 \\
\hline 19 & $10: 16$ & Unidentified & 208 & 73 & 1.20 \\
\hline 20 & $10: 50$ & Unidentified & 253 & 156 & 1.11 \\
\hline 21 & $11: 14$ & Cis- Nuciferol & 218 & 119 & 2.36 \\
\hline 22 & $11: 38$ & Trans- Nuciferol & 218 & 119 & 6.44 \\
\hline 23 & 12: 03 & Unidentified & 198 & 135 & 2.09 \\
\hline 24 & $13: 13$ & Unidentified * & -- & -- & 0.85 \\
\hline 25 & 15: 24 & Unidentified & -- & -- & 0.87 \\
\hline
\end{tabular}

* Concentration in the oil is not sufficent to be analysed by the mass relative percentage. 
component identified in both oils was $(+)-4(10)$ carene; its concentration in the leaves being almost ten times that in the flower heads (41.58 and $4.6 \%$ respectively). The variations in the other components of both oils may be attributed to the difference in the nature of the organs from which the oils were obtained.

However, cosmene which was detected in a previous investigation failed to show-up under experimental conditions adopted, a fact which may be attributed to its very high volatility at low temperature and its great instability ${ }^{(6)}$.

Screening for the antimicrobial activity of the oils (Table 3) showed pronounced activity against $\underline{\mathrm{S}}$ aureus, $\underline{\text { B. subtilis, }} \underline{\mathrm{S}}$. epidermides and $\underline{\mathrm{Pr}}$. vulgaris at a concentration of $400 \mu \mathrm{g} / \mathrm{ml}$.

\section{AKNOWLEDGMENT}

The author would like to thank Prof. Dr. T. S. El Alfy for his king help. Also thanks are due to the Medicinal, Aromatic and Poisonous Plants Research Centre, College of Pharmacy, King Saud University, Riyadh, Saudi Arabia for the GC-MS facilities and the antimicrobial testing.

1. Jones, S. B. and Luchsinger, A.E.; "Plant Systematics", McGraw- Hill Book Company, N.Y., P. 313 (1979).

2. Bailey, L.H.; "Manual of Cultivated Plants", 4th Ed., MacMillan Company, N.Y., P. 999 (1985).

3- Molzer, V.; "The Hamlyn Book of Garden Flower", Hamlyn, P. 287, (1979).

4- Boulos, L.; El-Hadidi, N.; "The Weed Flora of Egypt", the American University of Cairo Press, P. 29 (1984).

5- Hartwell, J. L.; "Cancer Treatment Reports", 8, 60 (1976)

6- Fieser, L.F. and Fieser, M.; "Introduction to Organic Chemistry" D.C. Heal th and Company, Boston, P. 499 (1957).

7- Glidemeister, E. and Hoffmann, Fr.; "Die Atherischen Ole", Akademie Verlag. Berlin, P. 620 (1961).

8. Nayler, P. and Whiting, M. C.; "J. Am Chem. Soc.", 4006 (1954).

9- El-Hifnawy, H. M.; M. Sc. thesis, Department of pharmacognosy, Cairo University. (1990). 
10- Eyptian Pharmacopoeia, 3rd Ed., Vol I, General Organization for Govermment Printing Office, Cairo, P. 31 (1984).

11- Mass Spectrometry Data Centre in collaboration with ICI Ltd." Eight Peak Index of Mass spectra, 2nd Ed. (1974).

12- Adams, R.; "Identification of Essential Oils by Ion Trap Mass Spectroscopy", Academic Press Inc. Harcourt Brace, Javonovish Publishers (1989).

13- Stenhagen, E., Abrahamsson, S. and McLafferty, F.W.; "Registry of Mass Spectral Data" Vol.1\&2, John Wiley \& Sons, N.Y., London (1976).

14 - Masada, Y.; Analysis of Essential Oils by Gas chromatography and Mass Spectrometry "John Wiley and Sons Inc. N.Y. (1976).

15- Cruichshank, R.; Dugnid, J. P.; Marion, B.P. and Swain, R.H.A., " Medicinal Microbiology", Churchil] Livingstone, London, 12th. Ed, P. 315. (1975).

\section{تحليل الزيت الميلر لنبات كوزهويس بيبناتيس(كاف)السنى ينهو في مصر لباستعمال كروماتوجرافيا الغـاز المتصلية بهيطياف الكتيسة}

\section{هـشيره هـمد الشريبع}

قسم العقاقير - كلية الصيدلة - جامعة القاهرة

تم في هذا البحث دراسة الزيت الطيار لكل من هامات وأورات نبات كوزموس بيبناتس(كاف) وذلك بإستخدام كروماتوجرافيا الغاز المتصلة ميطياف الكتلة . وقد أمكن التعرف على ستة عشر مركبا فى الهامات وستة أخرى فى الأورات

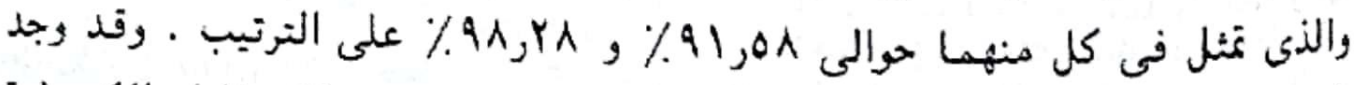
أن المواو الهبدروكربونية تمثل أعلى نسبة في كل من الزيتين ولكن المواد الكحولية

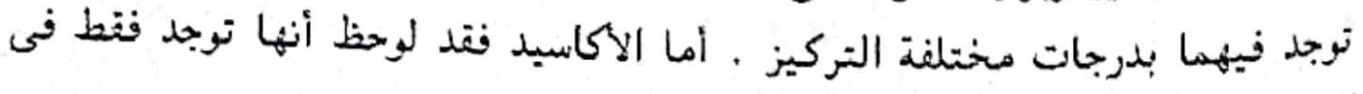

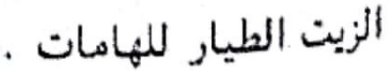

وقد وجد أن للزيت الطبار لكل من الهامات والأوراق تأثبر فعال ضد بعض لئ

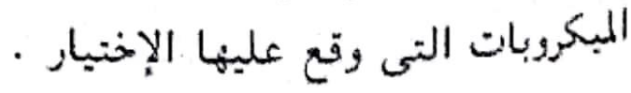

